\title{
REVIEW
}

\section{Conservation planning and the IUCN Red List}

\author{
M. Hoffmann ${ }^{1,2, *}$, T. M. Brooks ${ }^{1,3,4}$, G. A. B. da Fonseca ${ }^{5,6}$, C. Gascon ${ }^{7}$, \\ A. F. A. Hawkins ${ }^{7}$, R. E. James ${ }^{8}$, P. Langhammer ${ }^{9}$, R. A. Mittermeier ${ }^{7}$, J. D. Pilgrim ${ }^{10}$, \\ A. S. L. Rodrigues ${ }^{11}$, J. M. C. Silva ${ }^{12}$ \\ ${ }^{1}$ Center for Applied Biodiversity Science, Conservation International, 2011 Crystal Drive Suite 500, Arlington, \\ Virginia 22202, USA \\ ${ }^{2}$ IUCN Species Programme, IUCN — International Union for the Conservation of Nature, Rue Mauverney, 1196 Gland, \\ Switzerland \\ ${ }^{3}$ World Agroforestry Center (ICRAF), University of the Philippines Los Baños, Laguna 4031, Philippines \\ ${ }^{4}$ School of Geography and Environmental Studies, University of Tasmania, Hobart, Tasmania 7001, Australia \\ ${ }^{5}$ Global Environment Facility, 1818 H Street NW, Washington, DC 20433, USA \\ ${ }^{6}$ Departamento de Zoologia, Universidade Federal de Minas Gerais, Avenida Antonio Carlos 6627, Belo Horizonte MG \\ 31270-901, Brazil \\ ${ }^{7}$ Conservation International, 2011 Crystal Drive Suite 500, Arlington, Virginia 22202, USA \\ ${ }^{8}$ Conservation International Melanesia Centre for Biodiversity Conservation, PO Box 106, Waigani, NCD, \\ Papua New Guinea \\ ${ }^{9}$ School of Life Sciences, Arizona State University, PO Box 874501, Tempe, Arizona 85287-4501, USA \\ ${ }^{10}$ BirdLife International in Indochina, N6/2+3, Ngo 25, Lang Ha, Ba Dinh, Hanoi, Vietnam \\ ${ }^{11}$ Department of Zoology, University of Cambridge, Cambridge CB2 3EJ, UK \\ ${ }^{12}$ Conservation International - Brazil, Av. Gov. José Malcher 652, 2o. Andar, Ed. CAPEMI, Bairro: Nazaré, 66035-100, \\ Belém, Pará, Brazil
}

\begin{abstract}
Systematic conservation planning aims to identify comprehensive protected area networks that together will minimize biodiversity loss. Importantly, conservation planners seek to determine where to allocate limited resources first, particularly given the uneven spread of, and threats to, biodiversity. The International Union for the Conservation of Nature (IUCN) Red List of Threatened Species incorporates data not only on threats to species, but also on species distributions and ecological requirements. These temporal and spatial attributes, when combined with other datasets, have proven useful for determining the most urgent priority areas for conserving biodiversity, from the global level down to the scale of individual sites. Although many challenges remain, the increasing reliability and comprehensiveness of the IUCN Red List suggests that its role as a source of biodiversity data in systematic conservation planning is certain to expand dramatically.
\end{abstract}

KEY WORDS: IUCN Red List - Conservation planning · Threatened species • Biodiversity conservation $\cdot$ Protected areas

\section{INTRODUCTION}

The International Union for the Conservation of Nature (IUCN) Red List of Threatened Species (www. iucnredlist.org; hereafter referred to as the IUCN Red List) is the accepted standard for species global extinction risk (Lamoreux et al. 2003, Rodrigues et al. 2006). Traditionally, the IUCN Red List has served not only to highlight species at greatest risk of extinction, but also to guide conservation responses, primarily by identifying key and priority habitats for species, sites to be safeguarded, and actions required (Collar 1993-4, 1996a). While current IUCN guidelines (Standards and Petitions Working Group 2006) are explicit that the IUCN Red List should not be used in isolation for setting priorities or determining conservation responses, the IUCN Red List and conservation priority setting have proven inseparable (Mace \& Lande 1991, Mace 
1995). Both governmental and non-governmental organizations increasingly rely on the IUCN Red List to inform priorities, influence legislation, and guide conservation investment, particularly as its influence continues to grow (Fig. 1). One recent case concerns the new Resource Allocation Framework of the Global Environment Facility (GEF; the financial mechanism of the Convention on Biological Diversity) that incorporates IUCN Red List data to provide a relative ranking of countries for meeting the biodiversity objectives of the GEF (www.gefweb.org/documents/council_ documents/GEF_C27/documents/C.27.Inf.8.Rev.1_RAF. pdf). Although this profile has resulted in some degree of misuse, especially in the wake of a paucity of guidance on its appropriate application, it nevertheless provides a particularly important example of the power of the IUCN Red List to inform policy. Here, we briefly review the development of the IUCN Red List and its function in conservation planning, specifically, in identifying priority areas for biodiversity conservation; we also discuss challenges to improving its utility for this purpose. This review is particularly timely, because IUCN members have passed a resolution that identifies conservation planning as one of the most important areas for future expansion (Resolution RESWCC3.013 of the 2004 World Conservation Congress).

\section{EVOLUTION OF THE IUCN RED LIST}

Red Data Books were first conceived in the early 1960 s, as a 'register of threatened wildlife that includes definitions of degrees of threat' (Fitter \& Fitter 1987). Since then they have undergone significant evolution from simple lists of species and categories into an increasingly comprehensive compendium of conservation-related information on species (Rod-

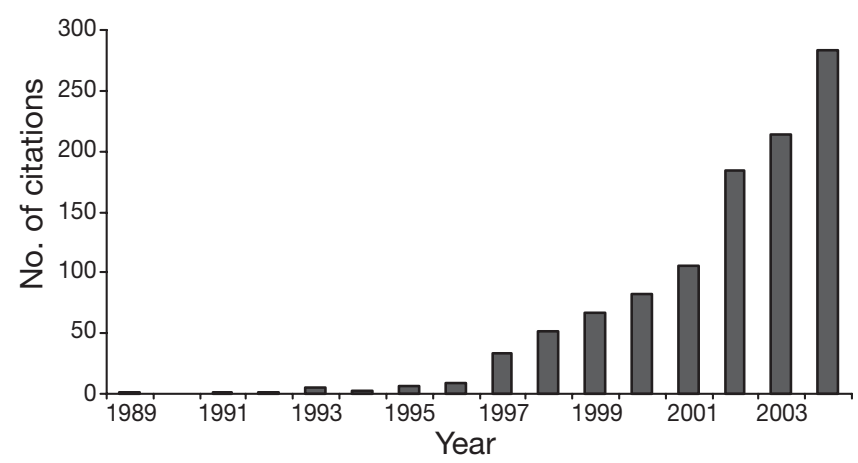

Fig. 1. Number of citations of the IUCN Red List per year, in peer-reviewed journals, up to and including 2004. Total of 1047 citations (Web of Science, http://isiwebofknowledge. com, April 25, 2005), either on the topic 'Red List' + 'IUCN', or citing at least one of the IUCN Red List main publications, or both rigues et al. 2006). An initial driving force behind this transformation was the role of such lists in setting priorities for conservation, especially at the level of prioritizing among species. The qualitatively defined categories and definitions were criticized for being subjective, raising concerns that assessments made by different authorities did not accurately reflect true extinction risks and skewed conservation priorities (Master 1991).

A revised risk-ranking system, incorporating quantitative categories and criteria (Mace \& Lande 1991), and adopted in 1994 (IUCN 1994), presented several advances, notably (1) enabling consistent application by different people, (2) being based around probabilistic assessment of extinction risk, (3) incorporation of a time-scale; (4) flexibility of data required and population units to which it applied, and (5) ability to handle uncertainty (Mace \& Lande 1991). Whereas the first IUCN Red List assessments depended on knowledge complemented by a large dose of subjective common sense, these new categories and criteria were designed to improve repeatability and consistency in the listing process.

Since the adoption of the most recent revision to the criteria in 2001 (IUCN 2001; Fig. 2, Table 1), there has been considerable emphasis on improving the taxonomic coverage, rigor, justification, and transparency of IUCN Red List assessments. For example, partly in response to criticisms (e.g. Mrosovsky 1997), assessments are now underpinned by mandatory supporting documentation, including information on geographic range and abundance, habitats, threats, and conservation actions (see www.iucnredlist.org); these assessments are consultative, now increasingly facilitated through workshops and web-based open-access systems (e.g. BirdLife International's Globally Threatened Bird forums; www.birdlifeforums.org), and peer-reviewed. As such, today's IUCN Red List is promoted not only as a credible and objective source of species' threat status with a remit beyond the cause of a few handpicked species, but as a growing data mine, which has improved its utility in conservation, including species-based conservation, policy and management, biodiversity evaluation, and monitoring (Rodrigues et al. 2006).

\section{EVOLUTION OF CONSERVATION PLANNING}

Priority-setting approaches that identify global priorities for conservation, such as the Global 200 ecoregions (Olson \& Dinerstein 1998), biodiversity hotspots (Myers et al. 2000), and Endemic Bird Areas (Stattersfield et al. 1998), have proven effective at directing conservation resources at a global scale to 


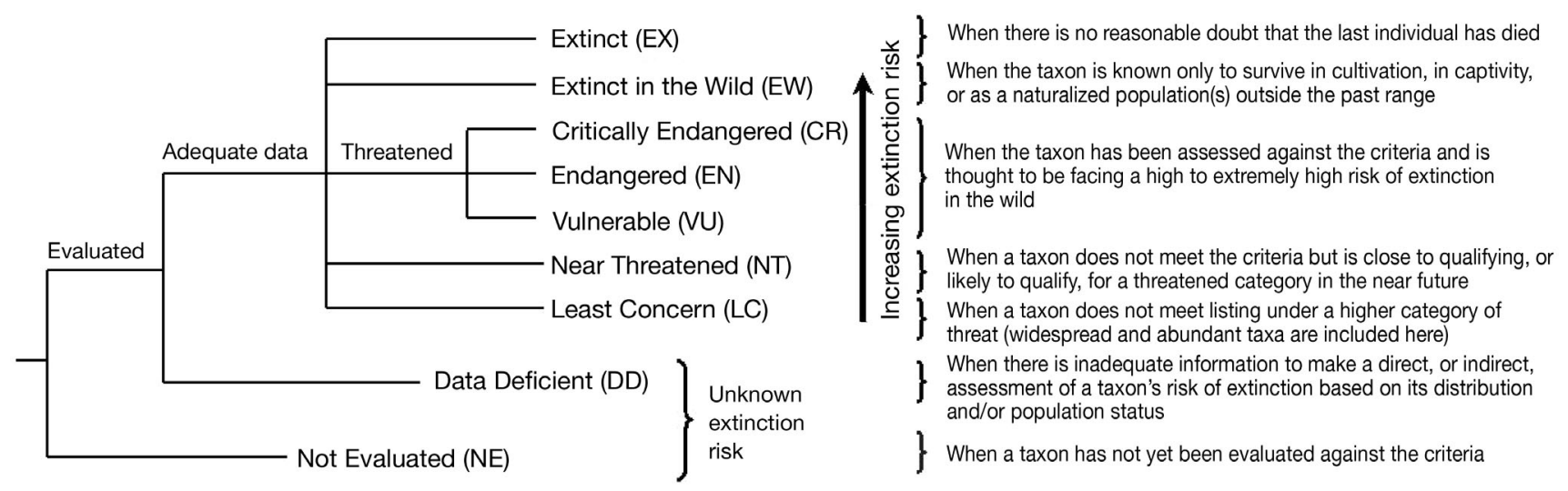

Fig. 2. The IUCN Red List categories (adapted, with permission, from IUCN 2001)

those regions most urgently in need of conservation investment (Brooks et al. 2006). However, these approaches are not designed, nor intended, to inform the identification of more fine-scale targets for conservation action, such as actual sites with biodiversity features that require safeguarding.

For most biodiversity, habitat loss and degradation is the most pervasive threat (affecting, for example, 85 to
$90 \%$ of threatened mammals, birds and amphibians; Baillie et al. 2004). Consequently, area-based action, or more specifically the mitigation of threats by means of the establishment of protected areas, is the most effective conservation response for safeguarding biodiversity (Bruner et al. 2001, Oliveira et al. 2007) — albeit not necessarily sufficient to ensure long-term viability in the face of threats such as climate change (Pounds et al.

Table 1. Simplified overview of the IUCN Red List criteria (adapted, with permission, from Butchart et al. 2004) (see IUCN 2001, Standard and Petitions Working Group 2006). EOO: extent of occurrence; AOO: area of occupancy; na: not applicable

\begin{tabular}{|c|c|c|c|c|}
\hline Criterion & $\begin{array}{l}\text { Critically } \\
\text { Endangered } \\
\quad(\mathrm{CR})\end{array}$ & $\begin{array}{l}\text { Endangered } \\
\qquad(\mathrm{EN})\end{array}$ & $\begin{array}{l}\text { Vulnerable } \\
\text { (VU) }\end{array}$ & Qualifiers and notes \\
\hline A1: reduction in population size & $\geq 90 \%$ & $\geq 70 \%$ & $\geq 50 \%$ & $\begin{array}{l}\text { Over } 10 \mathrm{yr} / 3 \text { generations } \mathrm{s}^{\mathrm{a}} \text { in the past, } \\
\text { where causes of the reduction are clearly } \\
\text { reversible AND understood AND have } \\
\text { ceased }\end{array}$ \\
\hline A2-4: reduction in population siz & $\geq 80 \%$ & $\geq 50 \%$ & $\geq 30 \%$ & $\begin{array}{l}\text { Over } 10 \mathrm{yr} / 3 \text { generations }{ }^{\mathrm{a}} \text { in past, future } \\
\text { or combination }\end{array}$ \\
\hline B1: small range (EOO) & $<100 \mathrm{~km}^{2}$ & $<5000 \mathrm{~km}^{2}$ & $<20000 \mathrm{~km}^{2}$ & $\begin{array}{l}\text { Plus } 2 \text { of }(1) \text { severe fragmentation/few } \\
\text { locations }(1, \leq 5, \leq 10),(2) \text { continuing } \\
\text { decline, (3) extreme fluctuation }\end{array}$ \\
\hline B2: small range (AOO) & $<10 \mathrm{~km}^{2}$ & $<500 \mathrm{~km}^{2}$ & $<2000 \mathrm{~km}^{2}$ & $\begin{array}{l}\text { Plus } 2 \text { of }(1) \text { severe fragmentation/few } \\
\text { locations }(1, \leq 5, \leq 10),(2) \text { continuing } \\
\text { decline, ( } 3 \text { ) extreme fluctuation }\end{array}$ \\
\hline C: small and declining population & $<250$ & $<2500$ & $<10000$ & $\begin{array}{l}\text { Mature individuals. Continuing decline } \\
\text { either (1) over specified rates and time } \\
\text { periods or (2) with (a) specified popula- } \\
\text { tion structure or (b) extreme fluctuation }\end{array}$ \\
\hline D1: very small population & $<50$ & $<250$ & $<1000$ & Mature individuals \\
\hline D2: very restricted population & na & na & $\begin{array}{c}<20 \mathrm{~km}^{2} \text { AOO or } \\
\leq 5 \text { locations }\end{array}$ & $\begin{array}{l}\text { Capable of becoming Critically Endan- } \\
\text { gered or even Extinct within a very short } \\
\text { time frame }\end{array}$ \\
\hline E: quantitative analysis & $\begin{array}{l}\geq 50 \% \text { in } \\
10 \mathrm{yr} / \\
3 \text { generations }{ }^{\mathrm{a}}\end{array}$ & $\begin{array}{c}\geq 20 \% \text { in } \\
10 \mathrm{yr} / \\
5 \text { generations }^{\mathrm{a}}\end{array}$ & $\begin{array}{l}\geq 10 \% \text { in } \\
100 \mathrm{yr}\end{array}$ & $\begin{array}{l}\text { Estimated extinction-risk using quanti- } \\
\text { tative models (e.g. population viability } \\
\text { analysis }\end{array}$ \\
\hline
\end{tabular}


2006) or disease (Walsh et al. 2003). Since forest remnants in fragmented landscapes that are already protected or available for conservation are often at high risk of loss (Gascon et al. 2000), conservation planning also considers matrix-level interventions that would improve the likelihood of the permanence of current interventions (e.g. da Fonseca et al. 2005). Such interventions represent a biodiversity conservation strategy in their own right (Szaro \& Johnston 1996, Boyd et al. in press), but are not the focus of the present paper.

Conservation planning aims to optimize the allocation of limited conservation resources by identifying comprehensive networks of sites or protected areas that together will contribute to the overall goal of minimizing biodiversity loss (Pressey et al. 1993, Margules \& Pressey 2000). This is particularly necessary since threats to biodiversity are distributed unevenly, with the result that investments must be made in some places with greater urgency than others, in order to prevent the loss of unique biodiversity. The significant advances made in the field of systematic conservation planning over the past 2 decades (e.g. Kirkpatrick 1983, Margules \& Pressey 2000), have seen the science move beyond theory to actual on-the-ground application (e.g. Cowling et al. 2003).

Such strategic decision-making requires information on both the spatial and temporal options available for inclusion in the planning framework. These 2 variables are commonly referred to as irreplaceability and vulnerability, respectively, in the conservation planning literature (Pressey \& Taffs 2001). Irreplaceability is a measure of the degree to which the spatial options available for conservation of unique biodiversity features are lost if that particular site is lost. At its most extreme, for example, a site containing the entire population of a species (e.g. Ricketts et al. 2005) is wholly irreplaceable - there are no other sites available (i.e. spatial options) for the conservation of that species (Pressey et al. 1994).

Vulnerability can be seen as a measure of irreplaceability, but on a temporal (i.e. time-sensitive) scale. Just as threatened species are more likely to be lost before non-threatened species, our options for conserving those sites facing high levels of vulnerability or threat are more limited in time, with places of higher threat likely to lose their biodiversity value sooner (Rodrigues et al. 2004a). Vulnerability combines with irreplaceability in complex ways to help define conservation priorities. Sites of simultaneously high values for both variables are the obvious highest priorities as they correspond to places where the loss of unique biodiversity is most imminent. Sites of high irreplaceability and low vulnerability require conservation but can afford to wait, often providing great opportunities for proactive, well-planned, conservation planning. Conservation in low irreplaceability regions can afford to be opportunity-driven, as there are plenty of spatial options. This may translate in conserving first the sites of lower vulnerability, as they are often those where conservation costs are lower and thus opportunity higher. Conceptually, all of the 9 global biodiversity conservation priority setting schemes fit within this framework of irreplaceability relative to vulnerability (Brooks et al. 2006).

In the long term, persistence of species requires not only maximizing their representation in places where they are currently present, but crucially also minimizing the probability of their being lost (Pressey et al. 2004). Scheduling priorities for conservation according to combined irreplaceability and vulnerability increases retention, as it focuses efforts on the places more likely to lose unique biodiversity (Pressey et al. 2004). Furthermore, ensuring species persistence also requires the conservation of the ecological processes on which they rely (Pressey et al. 2003). This is particularly important at the finer scales at which individual protected areas are created.

\section{USE OF THE IUCN RED LIST}

\section{Informing spatial options}

Information on the distribution and ecological requirements of species can help determine spatial options for biodiversity conservation. The most significant recent innovation of the IUCN Red List is the incorporation of spatial data. Range maps representing extent of occurrence (EOO ${ }^{1}$ ) are now available for nearly all the world's mammals, birds, and amphibians (Brooks et al. 2004). EOO data have proved extremely valuable in large-scale analyses, such as identifying centers of endemism (e.g. Orme et al. 2005), and assessing the comprehensiveness of existing protected area networks and identifying gaps in coverage (e.g. Rodrigues et al. 2004b). Rondinini et al. (2005) used information on habitat preferences to build habitat suitability models within geographic range (EOO) data to derive an estimated area of occupancy for African vertebrates in order to better assess shortfalls in the continent's reserve network. EOO data also inform conservation planning for area-demanding species, such as vultures, that require coordinated conservation action at regional or even continental scales (BirdLife International 2004b, Boyd et al. in press).

\footnotetext{
1Defined by IUCN (2001) as 'the area contained within the shortest continuous imaginary boundary which can be drawn to encompass all the known, inferred or projected sites of present occurrence of a taxon, excluding cases of vagrancy'
} 
However, EOO data have a coarse resolution and generally are useful only for highlighting priorities at very large global or continental scales. To inform decision-making at the site level, the level at which conservation implementation actually takes place, much finer spatial data are required (e.g. Pressey et al. 2003). For example, the identification of Important Bird Areas (IBAs), developed and promoted by BirdLife International since the early 1980s (Osieck \& Mörzer Bruyns 1981), has been facilitated by the compilation of locality data for threatened species in Red Data Books, which subsequently enables 'site-specific synthesis' (Collar 1993-4). Thus, initial identification of 'Key forests for threatened birds in Africa' (Collar \& Stuart 1988) and ultimately of 'Important Bird Areas in Africa and Associated Islands' (Fishpool \& Evans 2001) grew directly from the publication of 'Threatened birds of Africa and related islands' (Collar \& Stuart 1985). Three of the 4 quantitative criteria used to identify IBAs are intended to account for irreplaceability, by identifying sites $\underline{\underline{2}}^{\underline{2}}$ holding significant populations of species that are restricted in range, congregatory, or characteristic (as an assemblage) of a biome (Fishpool \& Evans 2001).

\section{Informing temporal options}

Information on threats and on the vulnerability of areas and species to these threats helps inform temporal options for biodiversity conservation, improving strategies for ensuring long-term persistence (rather than simple short-term representation) of biodiversity (Pressey et al. 2004). However, assessing vulnerability has proved problematic and various surrogates have been used to measure it. Wilson et al. (2005) categorized these into 4 groups based on types of data used: tenure and land use; environmental or spatial variables; threatened species data; and expert opinion. Here we focus on the third of these. Threatened species data (threat ranking and associated spatial attributes) have many advantages, among them the ability to integrate information across threatening processes, some of which are otherwise difficult to map regionally or globally (e.g. invasive species, hunting), or are difficult to measure (e.g. habitat degradation and loss in arid regions) (Wilson et al. 2005). Furthermore, IUCN

\footnotetext{
2Sites are defined as discrete areas that: (1) are different in character or habitat or ornithological importance from their surrounding areas; (2) exist as actual or potential protected areas or as areas which can be managed in some way for nature conservation; and (3) are, alone, or with other sites, self-sufficient areas which provide all the requirements of the species, when present, for which they are important (Fishpool \& Evans 2001)
}

Red List data provide valuable information for the identification of the processes (Pressey et al. 2003) that must be considered to ensure species' long-term persistence (e.g. interactions with other species, changes in fire regime, disruption of migratory routes).

Threatened species data have been used to highlight places where threatened biodiversity lacks protection and is, therefore, likely to be lost sooner, from the national (e.g. Komar 2002, Danielsen \& Treadaway 2004 ) to the global level. For example, Rodrigues et al. (2004a) highlighted priority regions for expanding the global protected-area network by incorporating a measure, weighted by extinction risk, of the number of species in each IUCN Red List category (Fig. 3).

Presence of threatened species also represents the 4 th (and primary) criterion for designating IBAs. Of the 7504 IBAs of global significance identified in 188 countries to date (Fig. 4; updated from BirdLife International 2004a). $66 \%$ were triggered based on the presence of a globally threatened species (M. Crosby pers. comm.). Increasingly, the IBA approach is being extended to other taxa, and has led to the identification of, among others, Important Plant Areas (Anderson 2002) and important sites for freshwater biodiversity (Darwall \& Vié 2005). To create a unified set of criteria and a taxonneutral umbrella for these initiatives, Eken et al. (2004) introduced the concept of Key Biodiversity Areas (KBAs) an approach that builds on the strengths and underlying methodology of IBAs. Currently, KBAs for non-avian taxa have been identified and are being safeguarded in over 100 countries around the world (Langhammer et al. 2007: Appendix I).

Since the number of sites identified in such initiatives is large, it has also proven possible to prioritize among them by applying thresholds based on combinations of vulnerability and irreplaceability. Ricketts et al. (2005) identified sites known to hold the entire population of at least one Critically Endangered or Endangered species - sites where species extinctions will occur unless immediate conservation action is taken. The nested nature of these high priority sites as a subset of other site-scale conservation targets (specifically KBAs, and their avian subset) is illustrated in Fig. 5, relative to the coarse-scale analysis of Rodrigues et al. (2004a), who used extent of occurrence data, demonstrating how the different resolutions of spatial data can be used to highlight priorities at different scales (see Reid 1998).

\section{CONSIDERATIONS AND CHALLENGES}

Although increasingly recognized and employed as a tool for conservation planning, there are several considerations that need to be borne in mind when using 

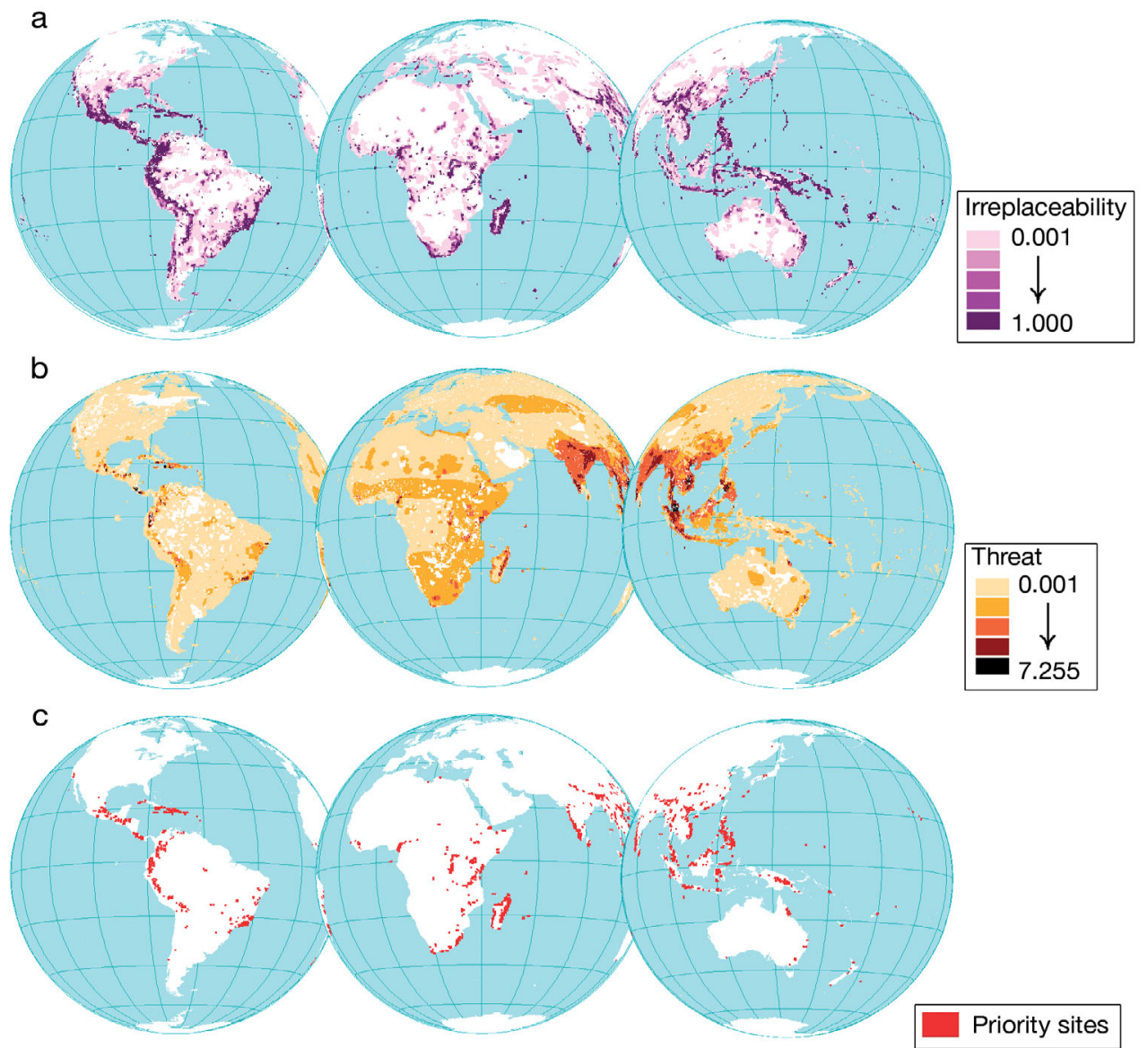

Fig. 3. Global distribution of (a) irreplaceability, (b) threat, and (c) priority for the expansion of the global protected-area network for the conservation of species of mammals, amphibians, turtles and threatened birds. Irreplaceability value ranges from $0 \%$ (a site that is not needed to achieve target goals) to $100 \%$ (a site for which there are no other replacements); threat values correspond to those calculated based on the extinction risk indicator of Butchart et al. (2004). The highest priority sites, shown in (c), are those that fall simulataneously into the higher classes of irreplaceability value $(\geq 0.9)$ and threat value (the top $5 \%$ in values of the extinction risk indicator). (Figure reproduced, with permission, from Rodrigues et al. 2004b; @American Institute of Biological Sciences)

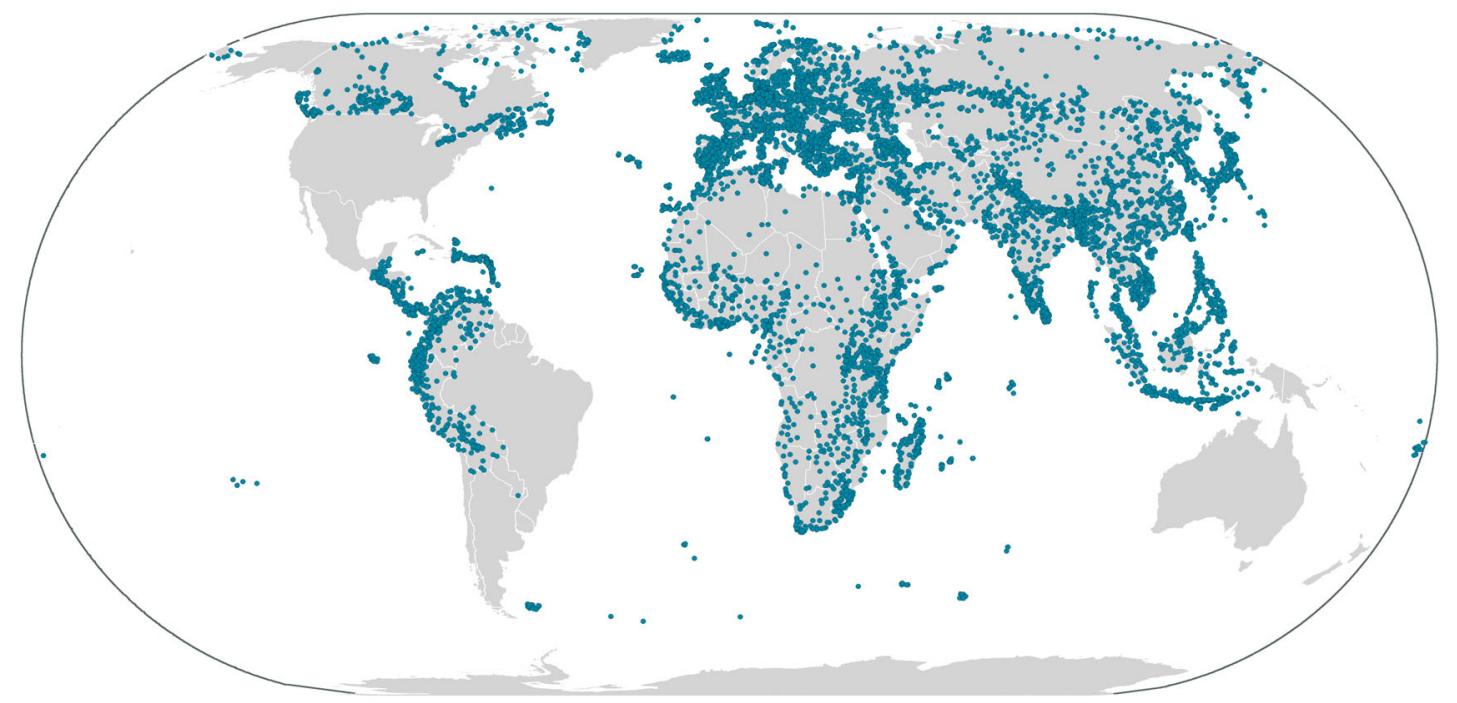

Fig. 4. The 7504 confirmed Important Bird Areas (IBAs) of global significance identified as of February 2008, based on the presence of significant populations of threatened species, restricted-range species, biome-restricted species, and congregatory species (data courtesy of BirdLife International). IBA identification is underway for Antarctica, Australia, New Zealand, Melanesia, Brazil and the southern cone, Mexico, and North America 


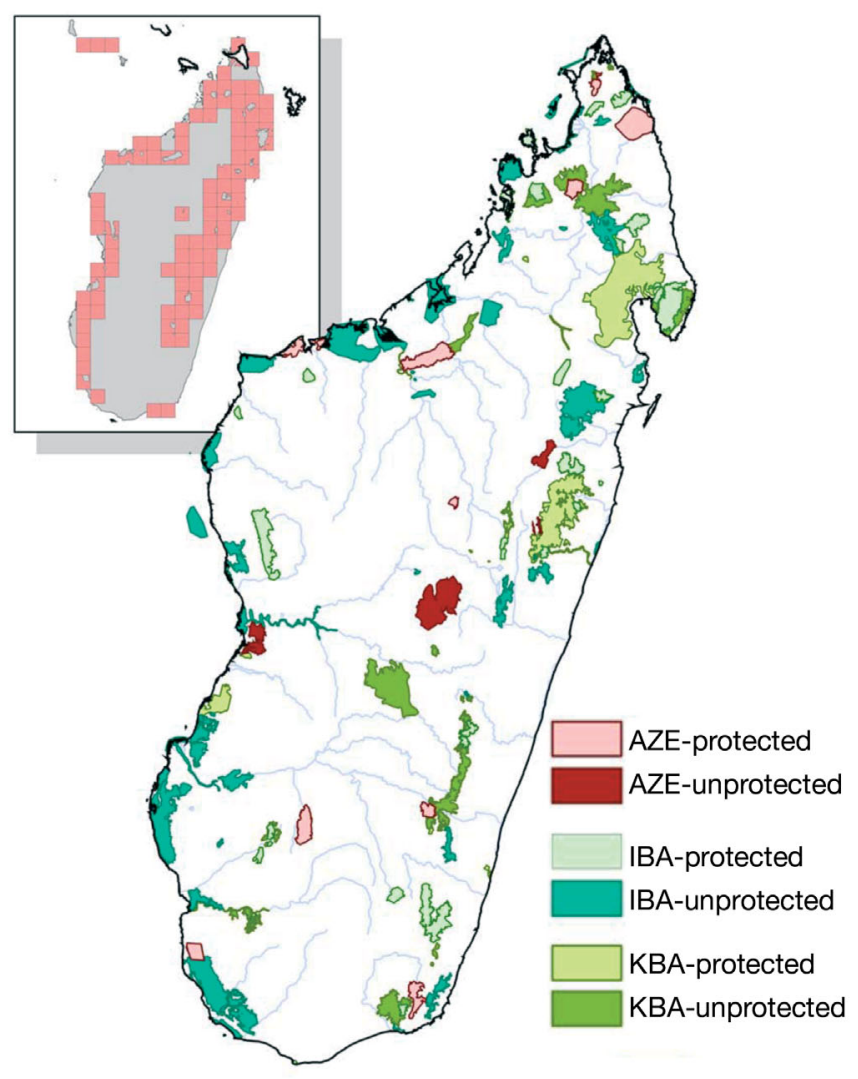

Fig. 5. Conservation priorities at the site scale in Madagascar, as determined using IUCN Red List data: Key Biodiversity Areas $\left(\mathrm{KBA}_{;} \mathrm{n}=117\right)$ identified from the distributions of threatened species covering 8 taxonomic groups (mammals, birds, amphibians, freshwater fishes, reptiles, arthropods, gastropods and plants) (preliminary data from Z. L. Rakotobe et al. unpubl. data); Important Bird Areas (IBA; $\mathrm{n}=78$ ), the avian subset of KBAs (modified from Fishpool \& Evans 2001); and Alliance for Zero Extinction (AZE) sites $(\mathrm{n}=16)$, the highest priority sites for biodiversity conservation, containing the entire population of at least one Critically Endangered or Endangered species (modified from Ricketts et al. 2005 using data from AZE; www.zeroextinction.org, v2.1). Inset: urgent priorities (pink grid squares) for expanding the network of protected areas in Madagascar (at a $1 / 4$-degree grid cell) ranked according to an Extinction Risk Index (data for mammals, birds, amphibians and turtles; modified from Rodrigues et al. 2004a)

the IUCN Red List for this purpose. We review some of these here, and highlight challenges that must be met in order to ensure that the IUCN Red List improves as a functional tool for conservation planners.

\section{Threatened species lists and conservation planning}

As with any threatened species list, the IUCN Red List alone is not sufficient to determine the priority allocation of resources for area-based biodiversity con- servation (e.g. Possingham et al. 2002). Indeed, the most common misuse of the IUCN Red List involves taking threat rankings at face value to define priorities. The IUCN explicitly notes, ' ... The category of threat is not necessarily sufficient to determine priorities for conservation action. The category of threat simply provides an assessment of the extinction risk under current circumstances' (IUCN 2001).

This does not reduce the value of the IUCN Red List, when correctly used, for informing spatial and temporal options in conservation planning, but it does mean that other relevant considerations, such as opportunities and costs (Wilson et al. 2006) should be incorporated. For example, species-based irreplaceability data and species-based threat data can yield a set of priority sites, such as a set of IBAs, for a given region. However, additional information must be incorporated through another type of vulnerability: site-based threat, i.e. a measure of threatening processes acting on each particular site. While species-based threat indicates whether the species occurring at a site has a high probability of global extinction, site-based threat informs the probability of that species' local extirpation through site destruction/degradation. Integrating this additional information greatly improves the prioritization results, thus maximizing the practical usefulness of the IUCN Red List data. Unfortunately, no mechanism currently exists for compiling information on sitelevel threat in a systematic and standardized way, although BirdLife's IBA monitoring framework provides a simple and repeatable system for assessing and monitoring degree of threat to sites and is now being implemented globally.

\section{Species concepts}

The influence of differing species concepts on the IUCN Red List has some relevance to conservation planning. The Biological Species Concept (Mayr 1963) has been the primary one used to date both in the IUCN Red List and in conservation planning. However, the increasing use of a Phylogenetic Species Concept (PSC; Cracraft 1983, Nixon \& Wheeler 1990) will lead to a much larger number of species being recognized (termed 'taxonomic inflation': Isaac et al. 2004, Mace 2004). Agapow et al. (2004) have estimated that adoption of the Phylogenetic Species Concept would result in a $48 \%$ increase in species numbers and an uplisting of $11 \%$ of species from Vulnerable to Endangered. This mainly occurs when 'splitting' biological species and subspecies into phylogenetic species, since this has direct influence on overall population size and geographic range size, key factors inherent in the IUCN Red List criteria (Collar 1996b). Not only would 
this lead to dilution of existing priorities with a flood of phylogenetic species (Collar 1997), but its patchy adoption to date has already resulted in inequalities in world species lists (Collar 2003), and concomitant taxonomic biases in the number of threatened species.

Whereas some studies indicate that use of different species concepts will produce different sets of priority conservation areas (e.g. Peterson \& Navarro-Sigüenza 1999), others suggest that general biodiversity patterns will not differ too greatly, at least at coarse scales (e.g. Dillon \& Fjeldså 2005). Even at the finer scale, changing taxonomy may yield little in the way of new conservation insights in terms of priorities (Collar 2007). An alternative approach is to directly incorporate phylogeny into priority setting (Crozier 1997, Isaac et al. 2007), although simulations suggest this may be unnecessary (Rodrigues et al. 2005). BirdLife International are currently developing criteria for recognizing species limits in order to apply a global standard and establish a consistent approach to bird taxonomy. This seems all the more necessary in light of, for example, Garnett \& Christidis (2007), who warn that the adoption of a PSC in the IUCN Red List would incur substantial transaction and opportunity costs with only marginal benefit for biodiversity conservation.

\section{Omission and commision errors}

Systematic conservation planning is sensitive to errors in the underlying species data. The errors facing species distribution data can be divided into 2 classes: errors of commission (when a species is mistakenly thought to be present and adequately protected at site where it does not occur) and errors of omission (when a species is mistakenly thought to be absent from a site where it could be protected). Where the goal is to prevent extinctions, omission errors are much less dangerous, although they remain problematic because they reduce the number of spatial options available for conservation plans and tend to result in reserve systems that are inadequate across species ranges. Commission errors, by contrast, could lead to species extinction, because conservationists could assume a species is conserved where it does not actually occur (Rondinini et al. 2006, Langhammer et al. 2007). EOO ranges (such as those generated as supporting documentation to the IUCN Red List assessments) may generate large commission errors if used in a manner that assumes homogenous species distributions; point locality data (such as those which inform identification of IBAs and KBAs) can minimize commission errors, but may contain large omission errors (Rondinini et al. 2006).

\section{Improving the rigor of IUCN Red List assessments}

Independent evaluations of several threatened species categorization systems have shown the IUCN Red List to be the most suitable for assessing species extinction risk (e.g. De Grammont \& Cuaron 2006). However, despite development of objective criteria (and a Users Working Group and Standards and Petitions Working Group within IUCN to promote consistency), consistency and subjectivity in the application of these within and across taxa remains an issue (Keith et al. 2004). The IUCN Red List criteria are designed to handle uncertainty (Akçakaya et al. 2000), but when there is inadequate information to make an assessment of extinction risk, the category Data Deficient must be used. Overly precautionary listing of Data Deficient species as threatened sometimes stems from concerns that species listed as Data Deficient are seldom beneficiaries of conservation investment (e.g. see Garnett et al. 2003). Such an approach to listing can lead to a confusion of conservation priorities with research priorities, and movement of valuable conservation resources away from species that need them most. Furthermore, classification in the Data Deficient category does not imply lack of threat; The Standards and Petitions Working Group (2006) explicitly notes 'it may be appropriate ...to give them the same degree of attention as threatened taxa until their status can be assessed.' Accordingly, a few conservation funds, such as the Conservation Leadership Programme (http://conservation.bp.com/), explicitly call for proposals for research on Data Deficient species.

Conversely, listing species genuinely threatened with extinction as Data Deficient, either because assessors demand substantial evidence that a species is threatened before making such a classification, or to side-step well intentioned but misguided government policies that restrict field research on threatened species, could result in such species not receiving conservation attention before it is too late (Pimenta et al. 2005, Stuart et al. 2005). Improved training in the use of the IUCN Red List criteria, particularly at a regional level, and assessor awareness of issues relating to criteria application can help ensure consistency and minimize discrepancies between the global IUCN Red List and national Red Lists.

\section{Capacity}

Perhaps the greatest challenge to the IUCN Red List is capacity. For example, assessments for all of Ecuador's endemic plants, some 4000 species, were completed by Valencia et al. (2000); to date, just 2159 species have been incorporated into the IUCN Red 
List. These delays are due to the time taken for extensive peer review of all assessments, which is exacerbated by the need for translation. Clearly, expediting assessment and subsequent integration of nationally and regionally endemic species into the global IUCN Red List is a top priority. While the above example highlights the need for increased centralized capacity, it is also necessary to encourage and facilitate national or regional IUCN Red Listing efforts that involve appropriate application of the regional guidelines and that include full supporting documentation. Partly to support this, IUCN's Species Survival Commission (SSC) runs regional IUCN Red List assessor-training workshops (Hilton-Taylor et al. 2000). In the interim, data originating from regional Red Listing initiatives can usefully inform regional-level conservation planning exercises, provided these data are used in tandem with existing global-level species data (see 'Global standardization').

\section{Coverage}

Whereas some taxa have been comprehensively assessed (all birds have been assessed 4 times since 1988; BirdLife International 2004 $\mathrm{a}^{\underline{3}}$ ), taxonomic and geographic biases exist. Around 41000 (2\%) of currently described species worldwide have been evaluated using the IUCN Red List categories and criteria. Only $4 \%$ of plants have been evaluated globally against the criteria, and a quarter of these are from Ecuador. Only 2 plant groups - cycads (Donaldson 2003) and conifers (Farjon \& Page 1999) - have been comprehensively (i.e. all species) assessed to date. Clearly, improved coverage of the IUCN Red List has direct relevance for conservation planning purposes.

The most effective leaps forward in expediting listings into the official IUCN Red List, and reducing geographic and taxonomic biases, will be made through the 'global assessments'. These initiatives coordinate status evaluations of all species in major taxonomic groups, incorporating inputs by IUCN/SSC Specialist Groups where these exist, and following the approach of BirdLife International. Global assessments maximize use of available resources and expert opinion to produce standardized, peer-reviewed, detailed accounts of the status of large numbers of species. The Global Amphibian Assessment was completed in 2004 (Stuart et al. 2004); a major reassessment of the world's mammals is due to be launched late 2008, and a Global Marine Species Assessment is underway, with the

${ }^{3} \mathrm{~A}$ fifth, complete assessment of all birds is due on 19 May 2008 (see www.birdlife.org) first-ever global assessment of, among other groups, all the world's sharks and reef-building corals soon to be completed. Such assessments are now gaining traction in international mandates, for example, as Target 2 of the '2010 Global Strategy for Plant Conservation' (www. biodiv.org/) of the Convention on Biological Diversity, which calls for 'a preliminary assessment of the conservation status of all known plant species' by 2010.

Existing conservation planning efforts using IUCN Red List data will often be setting priorities based on our knowledge of the best-known taxa, particularly vertebrates; other taxa also in need of conservation attention may, unnervingly, be falling through the cracks. Several analyses have revealed, for example, that freshwater taxa - both fish and invertebratesare among the most threatened in the world (Mace et al. 2005). However, they are also poorly studied and the coverage within the IUCN Red List is limited, although initiatives are underway to expedite the assessment of freshwater species globally (e.g. Darwall et al. 2005, Kottelat \& Freyhof 2007). This suggests that due to a lack of knowledge of the status of many taxonomic groups, conservation planners will need to rely, for now, on what we do know to serve as surrogates for the purpose of setting conservation priorities. Encouragingly, several recent studies (Brooks et al. 2001, Pain et al. 2005, Tushabe et al. 2006) have shown that, at least among IBAs, these sites successfully represented wider biodiversity, with Uganda's IBA network, for example, capturing at least $70 \%$ of the country's butterfly and woody plant species, $86 \%$ of its dragonflies and $97 \%$ of its birds. Such results suggest that, while by no means complete, a set of sites identified based on only a single taxon (in this case, IBAs) represents a central core of key sites upon which to build. More generally, a recent synthesis of studies of surrogacy in biodiversity conservation suggests that, while never perfect, cross-taxonomic surrogacy tends to be positive, and that conservation planning based on data for well-known taxonomic groups can proceed, albeit cautiously, under the assumption that it captures species in less well-known taxa within the same realm (Rodrigues \& Brooks 2007).

\section{Knowledge}

Even amongst the best-known species, gaps in knowledge remain. There is insufficient information on many species in globally assessed groups to make an adequate IUCN Red List assessment (e.g. $23 \%$ of amphibians; $\sim 1 \%$ of birds) and so they are listed as Data Deficient. This can help highlight regions requiring much additional survey work, such as the poorly 
studied New Guinea region, where $23 \%$ of Data Deficient birds are found (Baillie et al. 2004). Change in knowledge may also result in species moving from one category of threat to another; for example, 139 birds underwent a change in IUCN Red List category between 2000 and 2004 due to improved information on their distribution, population, trends and threats (Butchart et al. 2004). Such changes do not invalidate the use of IUCN Red List data in conservation planning, but conservation planners need to be iterative in setting priorities based on the best knowledge available at the time. Consequently, conservation planners should be aware that, relative to regions where knowledge gaps are minimal, their understanding of the conservation importance of poorly known regions is likely to change considerably.

\section{Global standardization}

Sub-global Red Lists now exist for many countries and regions. On the one hand, these are important for national policy (Miller et al. 2006), and sometimes incorporate data of higher quality than those utilized globally (Rodriguez et al. 2000). On the other hand, these lists may be hampered by strongly evidentiary or precautionary approaches to IUCN Red Listing (Stuart et al. 2005), inconsistent use of IUCN Red List criteria, and/or lack of sufficient transparent documentation to ensure assessments can feed through to the global IUCN Red List (Hilton-Taylor et al. 2000). In order to support regional listing efforts, IUCN has produced extensive guidelines for their application at the regional level (Gärdenfors et al. 2001, IUCN 2003) although there have been several calls for these to be refined (e.g. Eaton et al. 2005) - and appointed a National Red List Working Group to encourage best practice in national Red Listing efforts.

Individual countries, of course, have a responsibility to protect their national biodiversity assets. However, for the purposes of global conservation priority setting and planning, species listed on regional Red Lists but which are not globally threatened or country endemics do not have the same currency as those that are globally threatened on the IUCN Red List (Hilton-Taylor et al. 2000). There is an inherent bias in regional Red Lists towards locally rare, but globally widespread, species (particularly those at the edges of their ranges). For example, the herald petrel Pterodroma heraldica, listed as Least Concern on the global IUCN Red List is considered Critically Endangered on the Australian National Red List, because it is threatened in the small fraction of its total range that enters Australian territorial waters. Likewise, species may be globally threatened, but locally common, in which case countries where the species are still abundant have a special responsibility to invest in their conservation and ensure its security. For example, the dugong Dugong dugon is listed as Vulnerable on the IUCN Red List, but is not listed on the Australian National Red List, a country that harbors globally significant populations of the species. Conservation planning and action takes place at a sub-global scale, and so it is key that the global context is taken into account to ensure that these actions are complementary to global conservation efforts.

\section{CONCLUSIONS}

The IUCN Red List is now widely applied in conservation planning at various scales, particularly in the identification of site-based conservation targets. Such targets are slowly gaining formidable traction in national legislation: for example, the President of the Philippines, Gloria Macapagal-Arroyo, signed an Executive Order in November 2006 mandating the management and protection of KBAs as critical habitats under the Philippine Wildlife Act. Although conservation priorities generally should not be determined using threatened species lists alone, the practical value of the IUCN Red List in informing conservation planning at multiple scales has been demonstrated and is therefore likely to increase. In this regard, a complementary future direction will be the development of a quantitative methodology and criteria for measuring the threats at the site level (Langhammer et al. 2007). Some tough challenges remain to ensure that the IUCN Red List continues to develop as a functional tool in the conservation planner's toolbox, but these should not detract from its value in helping to inform both temporal and spatial options for conservation planning, thereby assisting in the selection of priority areas for biodiversity conservation on the ground.

Acknowledgements. We thank Leon Bennun, Luigi Boitani, Stuart Butchart, Nigel Collar, Holly Dublin, Graham Edgar, John Lamoreux, Craig Hilton-Taylor, David Knox, Georgina Mace, Michael Samways, Ali Stattersfield, Simon Stuart, and 4 anonymous reviewers for their valuable comments and help with this manuscript.

\section{LITERATURE CITED}

Agapow PM, Bininda-Emonds ORP, Crandall KA, Gittleman JL, Mace GM, Marshall JC, Purvis A (2004) The impact of species concept on biodiversity. Q Rev Biol 79:161-179

Akçakaya HR, Ferson S, Burgman MA, Keith DA, Mace GM, Todd CR (2000) Making consistent IUCN classifications under uncertainty. Conserv Biol 14:1001-1013

Anderson S (2002) Identifying important plant areas. Plantlife International, London 
Baillie JEM, Bennun LA, Brooks TM, Butchart SHM and others (2004) 2004 IUCN Red List of Threatened Species. A Global Species Assessment. IUCN, Gland and Cambridge

BirdLife International (2004a) State of the World's Birds 2004: indicators for our changing world. BirdLife International, Cambridge

BirdLife International (2004b) Tracking ocean wanderers: the global distribution of albatrosses and petrels. Results from the Global Procellariiform Tracking Workshop, 1-5 September, 2003, Gordon's Bay, South Africa. BirdLife International, Cambridge

Boyd C, Brooks TM, Butchart SHM, Edgar GJ and others (in press) Scale and the conservation of threatened species. Conserv Lett

Brooks T, Balmford A, Burgess N, Hansen LA and others (2001) Conservation priorities for birds and biodiversity: Do East African Important Bird Areas represent species diversity in other terrestrial vertebrate groups? Ostrich 15:3-12

Brooks TM, Bakarr MI, Boucher T, da Fonseca GAB and others (2004) Coverage provided by the global protectedarea system: Is it enough? Bioscience 54:1081-1091

Brooks TM, Mittermeier RA, da Fonseca GAB, Gerlach J and others (2006) Global biodiversity conservation priorities. Science 313:58-61

Bruner AG, Gullison RE, Rice RE, Fonseca GAB (2001) Effectiveness of parks in protecting tropical biodiversity. Science 291:125-128

Butchart SHM, Stattersfield AJ, Bennun LA, Shutes SM and others (2004) Measuring global trends in the status of biodiversity: Red List Indices for birds. PLoS Biol 2(12):2294-2304

Collar NJ (1993-4) Red data books, action plans, and the need for site-specific synthesis. Species 21 and 22: 132-133

Collar NJ (1996a) The reasons for Red Data Books. Oryx 30:121-130

Collar NJ (1996b) Species concepts and conservation: a response to Hazevoet. Bird Conserv Int 6:197-200

Collar NJ (1997) Taxonomy and conservation: chicken and egg. Bull Br Ornithol Club 117:122-136

Collar NJ (2003) How many bird species are there in Asia? Oriental Bird Club Bull 38:20-30

Collar NJ (2007) Philippine bird taxonomy and conservation: a commentary on Peterson (2006). Bird Conserv Int 17:103-113

Collar NJ, Stuart SN (1985) Threatened birds of Africa and related islands: the ICBP/IUCN Red Data Book. Third edition, part 1. International Council for Bird Preservation, and International Union for Conservation of Nature and Natural Resources, Cambridge

Collar NJ, Stuart SN (1988) Key forests for threatened birds in Africa. International Council for Bird Preservation and IUCN,

> Cowling RM, Pressey RL, Rouget M, Lombard AT (2003) A conservation plan for a global biodiversity hotspot-the Cape Floristic Region, South Africa. Biol Conserv 112:191-216

Cracraft J (1983) Species concepts and speciation analysis. Curr Ornithol 1:159-187

Crozier RH (1997) Preserving the information content of species: genetic diversity, phylogeny, and conservation worth. Annu Rev Ecol Syst 28:243-268

da Fonseca GAB, Sechrest W, Oglethorpe J (2005) Managing the matrix. In: Lovejoy TE, Hannah L (eds) Climate change and biodiversity. Yale University Press, New Haven, CT
Danielsen F, Treadaway CG (2004) Priority conservation areas for butterflies (Lepidoptera: Rhopalocera) in the Philippine islands. Anim Conserv 7:79-92

> Darwall WRT, Vié JC (2005) Identifying important sites for conservation of freshwater biodiversity: extending the species-based approach. Fish Manag Ecol 12:287-293

Darwall W, Smith K, Lowe T, Vié JC (2005) The status and distribution of freshwater biodiversity in Eastern Africa. IUCN/SSC Freshwater Biodiversity Assessment Programme. IUCN, Gland and Cambridge

> De Grammont PC, Cuaron AD (2006) An evaluation of threatened species categorization systems used on the American continent. Conserv Biol 20:14-27

> Dillon S, Fjeldså J (2005) The implications of different species concepts for describing biodiversity patterns and assessing conservation needs for African birds. Ecography 28:682-692

Donaldson JS (ed) (2003) Cycads. Status survey and conservation action plan. IUCN/SSC Cycad Specialist Group. IUCN, Gland and Cambridge

Eaton MA, Gregory RD, Noble DG, Robinson JA and others (2005) Regional IUCN Red Listing: the process as applied to birds in the United Kingdom. Conserv Biol 19:1557-1570

Eken G, Bennun L, Brooks T, Darwall W and others (2004) Key Biodiversity Areas as site conservation targets. Bioscience 54:1110-1118

Farjon A, Page CN (compilers) (1999) Conifers. Status survey and conservation action plan. IUCN/SSC Conifer Specialist Group. IUCN, Gland and Cambridge

Fishpool LDC, Evans MI (2001) Important Bird Areas in Africa and associated islands: Priority sites for conservation. Pisces Publications and BirdLife International, Newbury and Cambridge

Fitter R, Fitter M (1987) The road to extinction: problems of categorizing the status of taxa threatened with extinction. IUCN, Gland and Cambridge

Gärdenfors U, Hilton-Taylor C, Mace GM, Rodriguez JP (2001) The application of IUCN Red List criteria at regional levels. Conserv Biol 15:1206-1212

Garnett SC, Christidis L (2007) Implications of changing species definitions for conservation purposes. Bird Conserv Int 17:187-195

Garnett S, Crowley G, Balmford A (2003) The costs and effectiveness of funding the conservation of Australian threatened birds. Bioscience 53:658-665

Gascon C, Williamson GB, da Fonseca GAB (2000) Receding forest edges and vanishing reserves. Science 288: 1356-1358

Hilton-Taylor C, Mace GM, Capper DR, Collar NJ and others (2000) Assessment mismatches must be sorted out: they leave species at risk. Nature 404:541

Isaac NJB, Mallet J, Mace GM (2004) Taxonomic inflation: its influence on macroecology and conservation. Trends Ecol Evol 19:464-469

Isaac NJB, Turvey ST, Collen B, Waterman C, Baillie JEM (2007) Mammals on the EDGE: conservation priorities based on threat and phylogeny. PLOS One 2(3):e296

IUCN (1994) IUCN Red List Categories. IUCN Species Survival Commission. IUCN, Gland

IUCN (2001) IUCN Red List Categories and Criteria: version 3.1. IUCN, Gland and Cambridge

IUCN (2003) Guidelines for Application of IUCN Red List Criteria at Regional Levels: Version 3.0. IUCN Species Survival Commission. IUCN, Gland and Cambridge

Keith DA, McCarthy MA, Regan H, Regan T and others (2004) Protocols for listing threatened species can forecast extinction. Ecol Lett 7:1101-1108 
Kirkpatrick JB (1983) An iterative method for establishing priorities for the selection of nature reserves - an example from Tasmania. Biol Conserv 25:127-134

Komar O (2002) Priority conservation areas for birds in El Salvador. Anim Conserv 5:173-183

Kottelat M, Freyhof J (2007) Handbook of European freshwater fishes. Published by the authors, ISBN: 9782839902984

Lamoreux J, Akçakaya R, Bennun L, Collar NJ and others (2003) Value of the IUCN Red List. Trends Ecol Evol 18:214-215

Langhammer PF, Bakarr MI, Bennun LA, Brooks TM and others (2007) Identification and gap analysis of Key Biodiversity Areas: targets for comprehensive protected area systems. IUCN, Gland

Mace GM (1995) Classification of threatened species and its role in conservation planning. In: Lawton $\mathrm{JH}$, May RM (eds) Extinction rates. Oxford University Press, New York

Mace GM (2004) The role of taxonomy in species conservation. Phil Trans R Soc Lond Ser B 359:711-719

> Mace GM, Lande R (1991) Assessing extinction threats toward a reevaluation of IUCN threatened species categories. Conserv Biol 5:148-157

Mace GM, Baillie J, Masundire H, Ricketts TH and others (2005) Biodiversity. In: Hassan R, Scholes R, Ash N (eds) Ecosystems and human well-being. Vol 1. Current states and trends. Findings of the Condition and Trends Working Group. Millenium Exosystem Assessment series, Island Press, Washington, DC

> Margules CR, Pressey RL (2000) Systematic conservation planning. Nature 405:243-253

> Master LL (1991) Assessing threats and setting priorities for conservation. Conserv Biol 5:559-563

Mayr E (1963) Animal species and evolution. Harvard University Press, Cambridge, MA

Miller RM, Rodriguez JP, Aniskowicz-Fowler T, Bambaradeniya $\mathrm{C}$ and others (2006) Extinction risk and conservation priorities. Science 313(5786):414

> Mrosovsky N (1997) IUCN's credibility critically endangered. Nature 389:436

Myers N, Mittermeier RA, Mittermeier CG, da Fonseca GAB, Kent J (2000) Biodiversity hotspots for conservation priorities. Nature 403:853-858

Nixon KC, Wheeler QD (1990) An amplification of the phylogenetic species concept. Cladistics 6:211-223

> Oliveira PJC, Asner GP, Knapp DE, Almeyda A and others (2007) Land-use allocation protects the Peruvian Amazon. Science 317:1233-1236

Olson DM, Dinerstein E (1998) The Global 200: a representation approach to conserving the earth's most biologically valuable ecoregions. Conserv Biol 12:502-515

Orme CDL, Davies RG, Burgess M, Eigenbrod F and others (2005) Global hotspots of species richness are not congruent with endemism or threat. Nature 436:1016-1019

Osieck ER, Mörzer Bruyns MF (1981) Important Bird Areas in the European Community. International Council for Bird Preservation, Cambridge

Pain DJ, Fishpool L, Byaruhanga A, Arinaitwe J, Blamford A (2005) Biodiversity representation in Uganda's forest IBAs. Biol Conserv 125:133-138

Peterson AT, Navarro-Sigüenza AG (1999) Alternate species concepts as bases for determining priority conservation areas. Conserv Biol 13:427-431

> Pimenta BVS, Haddad CFB, Nascimento LB, Cruz CAG, Pombal JBJ (2005) Comment on 'Status and Trends of Amphibian Declines and Extinctions Worldwide'. Science 309:1999b
Possingham HP, Andelman SJ, Burgman MA, Medellin RA, Master LL, Keith DA (2002) Limits to the use of threatened species lists. Trends Ecol Evol 17:503-507

Pounds JA, Bustamante MR, Coloma LA, Consuegra JA and others (2006) Widespread amphibian extinctions from epidemic disease driven by global warming. Nature 439: 161-167

Pressey RL, Taffs KH (2001) Scheduling conservation action in production landscapes: priority areas in western New South Wales defined by irreplaceability and vulnerability to vegetation loss. Biol Conserv 100:355-376

> Pressey RL, Humphries CJ, Margules CR, Vane-Wright RI, Williams PH (1993) Beyond opportunism - key principles for systematic reserve selection. Trends Ecol Evol 8: $124-128$

> Pressey RL, Johnson IR, Wilson PD (1994) Shades of irreplaceability - towards a measure of the contribution of sites to a reservation goal. Biodivers Conserv 3:242-262

Pressey RL, Cowling RM, Rouget M (2003) Formulating conservation targets for biodiversity pattern and process in the Cape Floristic Region, South Africa. Biol Conserv 112:99-127

> Pressey RL, Watts ME, Barrett TW (2004) Is maximizing protection the same as minimizing loss? Efficiency and retention as alternative measures of the effectiveness of proposed reserves. Ecol Lett 7:1035-1046

$>$ Reid WV (1998) Biodiversity hotspots. Trends Ecol Evol 13:275-280

> Ricketts TH, Dinerstein E, Boucher T, Brooks TM and others (2005) Pinpointing and preventing imminent extinctions. Proc Natl Acad Sci USA 102:18497-18501

Rodrigues ASL, Brooks TM (2007) Shortcuts for biodiversity conservation planning: the effectiveness of surrogates. Annu Rev Ecol Evol Syst 38:713-737

Rodrigues ASL, Akçakaya HR, Andelman SJ, Bakarr MI and others (2004a) Global gap analysis: priorities for expanding the global protected area network. Bioscience 54: 1092-1100

Rodrigues ASL, Andelman SJ, Bakarr MI, Boitani L and others (2004b) Effectiveness of the global protected area network in representing species diversity. Nature 428: $640-643$

Rodrigues ASL, Brooks TM, Gaston KJ (2005) Integrating phylogenetic diversity in the selection of priority areas for conservation: Does it make a difference? In: Purvis A, Gittleman JL, Brooks TM (eds) Phylogeny and conservation. Cambridge University Press, Cambridge

> Rodrigues ASL, Pilgrim JD, Lamoreux JL, Hoffmann M, Brooks TM (2006) The value of the Red List for conservation. Trends Ecol Evol 21:71-76

Rodriguez JP, Ashenfelter G, Rojas-Suarez F, Garcia Fernandez JJ, Suarez L, Dobson AP (2000) Local data are vital to worldwide conservation. Nature 403:241

> Rondinini C, Stuart S, Boitani L (2005) Habitat suitability models and the shortfall in conservation planning for African vertebrates. Conserv Biol 19:1488-1497

> Rondinini C, Wilson KA, Boitani L, Grantham H, Possingham HP (2006) Tradeoffs of different types of species occurrence data for use in systematic conservation planning. Ecol Lett 9:1136-1145

Standards and Petitions Working Group (2006) Guidelines for using the IUCN Red List Categories and Criteria. Version 6.2. Prepared by the Standards and Petitions Working Group of the IUCN SSC Biodiversity Assessments SubCommittee in December 2006 (available at http:// intranet.iucn.org/webfiles/doc/SSC/RedList/RedList Guidelines.pdf) 
Stattersfield AJ, Crosby MJ, Long AJ, Wege DC (1998) Endemic Bird Areas of the World: priorities for biodiversity conservation. BirdLife International, Cambridge

Stuart SN, Chanson JS, Cox NA, Young BE, Rodrigues ASL, Fischman DL, Waller RW (2004) Status and trends of amphibian declines and extinctions worldwide. Science 306:1783-1786

Stuart SN, Chanson JS, Cox NA, Young BE, Rodrigues ASL, Fischman DL, Waller RW (2005) Response to Comment on 'Status and Trends of Amphibian Declines and Extinctions Worldwide'. Science 309:1999c

Szaro RC, Johnston DW (eds) (1996) Biodiversity in managed landscapes: theory and practice. Oxford University Press, New York

Tushabe H, Kalema J, Byaruhanga A, Asasira J and others

Editorial responsibility: David Roberts,

Kew, UK
(2006) A nationwide assessment of the biodiversity value of Uganda's Important Bird Areas network. Conserv Biol 20:85-99

Valencia R, Pitman N, León-Yánez S, Jorgensen PM (eds) (2000) Libro Rojo de las plantas endémicas del Ecuador. Herbario QCA, Pontificia Universidad Católica del Ecuador, Quito

Walsh PD, Abernethy KA, Bermejo M, Beyers R and others (2003) Catastrophic ape decline in western equatorial Africa. Nature 422:611-614

- Wilson K, Pressey RL, Newton A, Burgman M, Possingham H, Weston C (2005) Measuring and incorporating vulnerability in conservation planning. Environ Manag 35:527-543

- Wilson KA, McBride MF, Bode M, Possingham HP (2006) Prioritizing global conservation efforts. Nature 440:337-340

Submitted: November 22, 2007; Accepted: February 18, 2008 Proofs received from author(s): April 14, 2008 